Counsellia: Jurnal Bimbingan dan Konseling

Volume 11 (1) 95 - 105 Mei 2021

ISSN: 2088-3072 (Print) / 2477-5886 (Online)

DOI: $10.25273 /$ counsellia.v11i18882

Available online at: http://e-journal.unipma.ac.id/index.php/JBK

\title{
Pengembangan Permainan Ular Tangga Keyakinan dalam Peningkatan Efikasi Diri Siswa SMP
}

\author{
Devi Putri Wulandari ${ }^{1} 凶$, Cindy Asli Pravesti ${ }^{2}$. \\ ${ }^{1}$ Bimbingan dan Konseling, Fakultas Pedagogi dan Psikologi, Universitas PGRI Adi \\ Buana Surabaya. \\ email: $₫$ devi.putri.dp.dp@gmail.com \\ ${ }^{2}$ Program Studi Bimbingan dan Konseling, Fakultas Pedagogi dan Pikologi, \\ Universitas PGRI Adi Buana Surabaya. \\ email: cindyasli@unipasby.ac.id
}

Abstrak: Tujuan penelitian ini yaitu untuk mengembangkan media permainan Ular Tangga Keyakinan yang efektif untuk meningkatkan efikasi diri siswa di SMP Negeri 2 Krian. Metode penelitian dan pengembangan ini menggunakan prosedur penelitian dan pengembangan dengan langkah-langkah: 1) studi pendahuluan, 2) pengembangan produk, dan 3) uji produk. Berdasarkan penilaian ahli materi dihasilkan skor rata-rata 0,46 dengan kategori cukup layak. Berdasarkan penilaian ahli media dihasilkan skor rata-rata 0,69 dengan kategori layak. Hasil penilaian uji pengguna didapatkan hasil sebesar 92,3\% dengan kategori sangat valid atau dapat digunakan tanpa revisi. Berdasarkan hasil uji lapangan terbatas, diperoleh $\mathrm{t}$ hitung 4,058>t tabel 3,182 dan Sig (2tailed) sebesar $0,027<0,05$, sehingga $\mathrm{H}_{0}$ ditolak dan $\mathrm{H}_{\mathrm{a}}$ diterima. Maka dapat disimpulkan bahwa media permainan Ular Tangga Keyakinan efektif untuk meningkatkan efikasi diri siswa.

Kata Kunci: Efikasi Diri, Media Bimbingan Dan Konseling, Permainan Ular Tangga Keyakinan

Abstract: The purpose of this research is to develop a game media of Snakes and Ladder of Faith which is effective for increasing the self-efficacy of students at SMP Negeri 2 Krian. This research and development method uses a research and development procedure with the following steps: 1) preliminary study, 2) product development, and 3) product testing. Based on the material expert's assessment, an average score of 0.46 was obtained which was categorized as quite feasible. Based on the media expert's assessment, an average score of 0.69 was obtained with the feasible category. The results of the user test assessment obtained results of $92.3 \%$ with the very valid category or can be used without revision. Based on the results of the limited field test, it was obtained that t count 4.058>t table 3.182 and Sig (2tailed) $0.027<0.05$, so that $\mathrm{H}_{0}$ was rejected and $\mathrm{H}_{\mathrm{a}}$ was accepted. So, it can be concluded that the game media, Snake and Ladder of Faith, is effective for increasing student self-efficacy.

Keywords: Self-Efficacy, Guidance and Counseling Media, The Game of Snakes and Ladder of Faith

Received ; Accepted ; Published

Citation: Wulandari, Pravesti. (2021). Pengembangan Permainan Ular Tangga Keyakinan Dalam Peningkatan Efikasi Diri Siswa SMP. Counsellia: Jurnal Bimbingan dan Konseling, 11(1), 95-105. Doi.org/10.25273/counsellia.v11i18882 


\section{$(\mathrm{Cc})$ BY-NC-SA}

Copyright (C2021 Counsellia: Bimbingan dan Konseling

Published by Universitas PGRI Madiun. This work is licensed under the Creative Commons Attribution-NonCommercialShareAlike 4.0 International License

\section{PENDAHULUAN}

Keyakinan diri pada siswa sangatlah penting (Fratturar, 2018). Siswa yang mempunyai keyakinan yang kuat, percaya bahwa dirinya dapat menyelesaikan tugas yang sulit sekalipun. Ketika mereka menghadapi kegagalan yang akan datang, mereka akan berusaha untuk meningkatkan dan mempertahankan upaya mereka untuk menuju tujuan yang sukses. Mereka yakin bahwa mereka bisa mengendalikan kesulitan atau situasi yang mengancam keyakinan mereka. Sebaliknya, siswa yang meragukan atau tidak yakin dengan kemampuannya untuk menyelesaikan tugas yang sulit, mereka akan menganggap sebagai ancaman sehingga muncul sifat mudah menyerah pada diri siswa. Efikasi diri meningkat saat siswa mencatat kemajuan, mencapai tujuan, dan menetapkan tantangan baru (Fratturar, 2018).

Berdasarkan hasil penelitian yang dilakukan oleh Zulfia (2018) tingkat efikasi diri siswa SMPN 2 Jabon, Sidoarjo pada kategor: ${ }^{\circ}$ ang dengan presentase sebesar 66\% dari 136 siswa hanya 90 siswa yang memiliki efikas 1 ategori sedang. Artinya bahwa siswa SMP belum sepenuhnya yakin akan kemampuan dırınya dalam mencapai tujuan dan hasil tertentu. Keyakinan diri terhadap sesuatu hal menjadikan siswa lebih mempertimbangkan segala sesuatu dengan matang atau keyakinan yang kuat. Melalui masa-masa ini siswa perlu dorongan dan bantuan dari keluarga, teman, dan guru di sekolah agar keyakinan diri mereka bisa di arahkan kearah yang positif. Problematika yang menjadikan siswa mempunyai efikasi diri pada katerogi sedang ialah ketidakyakinan mereka untuk melakukan sesuatu hal yang menantang, ketidakyakinan mereka akan kemampuan untuk menyelasaikan berbagai tugas, dan ketidakyakinan mereka akan berhasil dalam mengatasi permasalahan dalam hidupnya.

Berdasarkan wawancara dengan guru BK dan dua orang siswa di SMP Negeri 2 Krian, siswa kurang yakin akan kemampuan dirinya untuk mengerjakan sesuatu hal yang sulit atau dihadapkan pada situasi yang sulit. Kebanyakan mereka lebih suka atau tertarik dengan sesuatu yang mudah yang tidak mempersulit diri sendiri atau menjadi beban. Seperti saat diberikan tugas yang sulit, kurang yakin saat tampil di depan kelas, kurang yakin bisa mengerjakan tugas atau ujian, dan kurang yakin dalam mengambil keputusan. Mereka merasa ragu akan kemampuannya dalam mencapai keberhasilan dengan artian bisa mencapai tujuan yang diinginkan. Seperti situasi di mana mengharuskan mereka untuk menyelesaikan tugas sekolah, tugas rumah, dan apalagi saat siswa mempunyai masalah dalam hidupnya. Mereka kurang yakin akan bisa menyelesaikan dan melewati semua hal tersebut dalam waktu bersamaan. Mereka merasa memiliki sifat pesimis, mudah cemas, bersikap acuh terhadap sesuatu hal, ragu dalam menentukan tindakan atau pilihan, dan mudah putus asa.

Menurut Bandura (1997) self-effcacy adalah bagian penting dalam teori sosial kognitif yang diartikan sebagai kepercayaan terhadap kemampuan dirinya untuk mencapai suatu hasil yang diharapkan. Efikasi diri merupakan keyakinan seseorang terhadap tindakannya untuk mencapai sesuatu yang diharapkan (Alwisol, 2009). Individu akan melakukan suatu tindakan untuk mencapai tujuan yang diinginkan agar mendapatkan keyakinan diri dalam hidupnya. Sedangkan Ghufron (2010), keyakinan diri adalah kemampuan individu dalam melaukan tugas untuk mencapai asil tertentu. Alwisol (2009) menyatakan bahwa efikasi atau keyakinan dapat diperoleh, diubah, dan ditingkatkan atau diturunkan yaitu melalui pencapaian prestasi pengalaman vikarius melalui model sosial, persuasi sosial melalui dukungan sosial dan kondisi emosi. Bandura (1997) self-efficacy terdiri dari tiga aspek yaitu level (tingkatan), generality (generalisasi), dan strength (kekuatan). Seseorang dengan efikasi diri yang tinggi cenderung melakukan sesuatu dengan usaha yang besar dan penuh tantangan, sebaliknya apabila seseorang dengan keyakinan diri yang rendah cenderung memilih usaha atau cara yang lebih mudah. 
Efikasi diri sangat penting bagi siswa karena keyakinan diri dapat berpengaruh di masa depan seseorang, untuk itu keyakinan diri akan kemampuannya perlu dibentuk sejak dini (Alwisol, 2009). Semakin tinggi efikasi diri seseorang akan berpengaruh pada tujuan dan komitmen yang ditetapkan dan sebaliknya (Puri \& Astuti 2018). Efikasi diri siswa pada kategori rendah dan sedang, bila tidak segera diatasi akan berdampak pada terhambatnya perkembangan kognitif siswa. Siswa akan mengalami banyak hambatan untuk menuju proses yang diinginkan dalam perkembangan hidupnya, seperti pencapaian prestasi akademik maupun non akademik. Menurut Anggriana, et al (2016) efikasi diri merupakan bagian dari keberhasilan performansi serta pelaksanaan tugas, efikasi diri juga sangat berpengaruh terhadap pola pikir, gerakan emosional, dan saat kita mengambil keputusan.

Peningkatan efikasi diri siswa dapat dilatih melalui penggunaan media, seperti hasil penelitian yang dilakuan Setyaputri (2015) bahwa terdapat pengaruh yang efektif dalam penggunaan media roda pelangi pada peningkatan efikasi diri siswa SMP saat menghadapi ujian. Media lain yang diharapkan dapat meningkatkan keyainan diri siswa SMP yaitu permainan Ular Tangga. Arsyad (2007) media yaitu perantara yang digunakan sebagai penyampaian pesan dan informasi. Media pembelajaran dengan ular tangga merupakan hasil pengembangan dari permainan tradisional (Afandi, 2015).

Ular Tangga diibaratkan sebagai permainan dalam perjalanan hidup menuju satu tujuan hidup kadang kala dihadapkan pada keberhasilan atau kegagalan (Duma, 2015). Media Ular Tangga yang digunakan dalam penelitian ini adalah memiliki bentuk persegi panjang yang dilengkapi dengan kotak kecil dari angka 1-50, permainan ini dimainkan oleh dua anak atau lebih. Melsi (2015) permainan ular tangga disesuaikan dengan karakter siswa dalam meningkatkan efikasi diri siswa. Media pembelajaran dengan ular tangga mempunyai kelebihan antara lain, 1) belajar sambil bermain, 2) menarik dan murah, 3) memudahkan siswa dalam belajar, dan 4) siswa belajar secara berkelompok.

Permaianan ular tangga yang berisikan kotak-kotak kecil mempunyai makna bahwa dalam setiap kotak tersebut terdapat kata-kata motivasi yang diharapkan setiap kali siswa melangkah dari kotak satu ke kotak lain dapat mengalami peningkatan efikasi dirinya yang dikemas dengan pertanyaan dan pernyataan yang ada dalam kotak. Tujuan permainan snake ledder yaitu melatih ketelitian siswa, kesabaran siswa, dan kepercayaan diri siswa (Duma, 2015). Percaya diri adalah komponen atau bagian dari keyakinan diri. Tumu (2014) menyatakan bahwa kepercayaan diri ada kaitannya dengan keyakinan diri, siswa dengan efikasi diri tinggi belum tentu memiliki percaya diri yang tinggi dan sebaliknya percaya diri yang tinggi tentu akan mempunyai efikasi diri, untuk itu kepercayaan diri adalah salah satu faktor pendukung untuk meningkatkan efikasi diri siswa.

Hasil penelitian Makaria, et al (2019) tentang hubungan percaya diri dan efikasi diri akademik terhadap mahasiswa BK, menunjukkan adanya korelasi positif terhadap kepercayaan diri dan keyakinan diri mahasiswa. Mahasiswa yang yakin akan kemampuannnya, akan mudah dan percaya diri bisa menyelesaikan tugas akademiknya. Salah satu tujuan dari permainan ular tangga yaitu melatih kepercayaan diri, percaya diri didapatkan melalui lemparan dadu yang membawa pemain menuju tangga-tangga yang akan mengarahkan pemain menuju kotak terakhir yang dinobatkan sebagai pemenang.

Manfaat dari permainan ular tangga yaitu bisa membuat pemain merasa senang dan semangat dalam melakuan permainan. Tujuan dan manfaat dari permainan ular tangga di atas bisa digunakan untuk meningkatkan efikasi diri siswa, dengan adanya kepercayaan diri akan kemampuan yang dimiliki dan kesabaran untuk mencapai apa yang diharapkan, maka tingkat efikasi diri siswa menjadi meningkat. Suasana yang menyenangkan juga berpengaruh terhadap keyakinan diri akan ketepatan dalam memilih, seseorang dengan suasana hati yang menyenangkan bisa menjadikan mereka berpikir positif tentang kemampuan yang dimilikinya, 
berbeda dengan orang yang memiliki suasana hati tidak menyenangkan akan sering mengambil suatu keputusan tanpa melihat sebab dan akibat yang akan dilakukan.

Penelitian ini hanya berfokus untuk pegembangan permainan Ular Tangga Keyakinan dalam peningkatan efikasi diri siswa. Rumusan masalah ini adalah 1) Apakah penggunaan media permainan UTK (Ular Tangga Keyakinan) efektif untuk meningkatkan keyakinan diri siswa SMP? 2) Bagaimana rancangan media permainan UTK?, dan 3) Bagaimana panduan media permainan UTK?. Tujuan penelitian ini yaitu menguji kefektifan media permainan Ular Tangga Keyakinan melalui uji ahli yang bisa digunakan sebagai media BK, memperoleh rancangan media yang dapat diterima siswa, dan menghasilkan panduan media permainan yang efektif untuk meningkatkan keyakinan diri siswa.

\section{METODE PENELITIAN}

\section{Rancangan Penelitian}

Peneliti menggunakan prosedur penelitian pengembangan yang diadaptasi dari langkah pengembangan Borg and Gall (1989) yang dimodifikasi oleh Sukmadinata (2016). Langkah pengembangan Borg and Gall (1989) dimodifikasi sesuai keadaan dan hambatan yang ada, dalam penelitian ini menggunakan tiga tahap dari (Sukmadinata, 2016). Menurut (Sukmadinata, 2016) langkah penelitian (RnD) secara garis besar meliputi tiga tahap, yaitu 1) Studi Pendahuluan, 2) Pengembangan Produk, dan 3) Uji Produk. Studi pendahuluan ini adalah tahap awal penelitian dan pengembangan. Tahap ini terdiri atas tiga langkah yaitu, (1) Survei Lapangan, (2) Studi Kepustakaan, dan (3) Penyusunan Produk Awal atau Draft Model. Setelah melaksanakan tahap pertama, selanjutnya melaksanakan tahap pengembangan produk. Tahap kedua ini, kegiatan yang dilakukan adalah penentuan materi dan penyusunan panduan untuk pelaksanaan permainan Ular Tangga Keyakinan. Terakhir adalah tahap uji produk, dalam langkah ini yang dilaksanakan ialah uji ahli, uji pengguna, dan uji lapangan terbatas.

\section{Sumber Data}

Uji produk dilakukan oleh ahli materi, ahli media, dan calon pengguna (guru BK). Populasi yang digunakan dalam penelitian ini yaitu siswa kelas VIII-E SMP Negeri 2 Krian sebayak 27 siswa. Sampel penelitian ini dibagi menjadi tiga yaitu uji ahli, uji pengguna, dan uji lapangan terbatas. Pengambilan sampel penelitian untuk uji ahli dan uji pengguna menggunakan purposive sampling, dalam penentuan ini ada kriteria khusus untuk uji ahli yaitu memiliki latar belakang minimal S2 Bimbingan dan Konseling (ahli materi) dan S2 lingkup media BK (ahli media), sedangkan kriteria untuk uji pengguna yaitu telah menjadi guru BK minimal 3 tahun dan aktif dalam kegiatan bimbingan dan konseling. Pengambilan sampel untuk uji lapangan terbatas menggunakan simple random sampling. Uji ahli terdiri dari dua ahli materi BK, dua ahli pengembangan media BK, uji pengguna terdiri dari satu guru BK SMP Negeri 2 Krian, dan uji lapangan terbatas yaitu 4 siswa SMP Negeri 2 Krian.

\section{Teknik Pengumpulan Data}

Metode pengumpulan data menggunakan instrumen skala efikasi diri dan wawancara tidak terstruktur. Instrumen tersebut dipergunakan untuk mengukur tingkat keyakinan diri siswa sebelum dan sesudah diberikan perlakuan dengan media permainan UTK. Pengujian reliabilitas dan validitas instrumen skala efikasi diri menggunakan Cronbach Alpha dengan bantuan program SPSS versi 25. Reliabilitas data diperoleh skor sebesar 0,898 >0,164 ( $\mathrm{r}$ tabel). Validitas data menunjukkan $r$ tabel sebesar 0,1646 dari 40 item pernyataan didapat 36 valid dan 4 gugur dengan koefisien terendah-tertinggi sebesar $-0,020-0,659$. Wawancara tidak tersruktur atau terbuka digunakan peneliti untuk memperoleh informasi atau data siswa dari guru BK dan siswa yang berkaitan dengan bagaimana keyakinan diri siswa di sekolah. 


\section{Teknik Analisis Data}

Analisis data dalam penelitian ini menggunakan format tabulasi data Inter-rater Agreement Model dari (Gregory, 2011) untuk menentukan data dari penilaian uji ahli dan uji pengguna. Berikut adalah gambar Inter-rater Agreement Model.

\begin{tabular}{|c|c|c|c|}
\hline \multirow{3}{*}{$\begin{array}{l}\text { PENDAPAT } \\
\text { AHLI } 2\end{array}$} & \multirow{3}{*}{$\begin{array}{l}\text { Relevensi } \\
\text { rendah (1-2) } \\
\text { Relevensi } \\
\text { tinggi }(3-4)\end{array}$} & $\begin{array}{l}\text { Relevansi } \\
\text { rendah (1-2) }\end{array}$ & $\begin{array}{l}\text { Relevansi } \\
\text { tinggi }(3-4)\end{array}$ \\
\hline & & A & B \\
\hline & & $c$ & $D$ \\
\hline
\end{tabular}

Gambar 3.2 Inter-mater Agresment Model. Sumber. Gregory (2011)

\section{HASIL DAN PEMBAHASAN}

\section{Hasil}

Uji ahli materi BK dilakukan oleh Dimas Ardika Miftah Farid, S.Pd., M.Pd. dan Maghfirotul Lathifah, M.Pd., sedangkan uji ahli pengembangan media BK dilaksanakan Elia Firda Mufidah, M.Pd dan Ayong Lianawati, M.Pd. Uji Ahli materi memfokuskan pada isi atau materi media permainan Ular Tangga Keyakinan, sedangakan Ahli media BK difokuskan ke viualisasi media permainan Ular Tangga Keyakinan.

Tabel 1 Penilaian Uji Ahli Materi

\begin{tabular}{|c|c|c|c|c|}
\hline \multirow{2}{*}{ No } & \multirow{2}{*}{ Aspek yang dinilai } & \multicolumn{2}{|c|}{ Penilaian } & \multirow{2}{*}{$\begin{array}{c}\text { Tabulasi } \\
\text { silang }\end{array}$} \\
\hline & & Ahli 1 & Ahli 2 & \\
\hline \multicolumn{5}{|c|}{ Ketepatan } \\
\hline 1 & $\begin{array}{l}\text { Ketepatan penggunaan bahasa dengan kemampuan siswa } \\
\text { SMP }\end{array}$ & 4 & 3 & B \\
\hline 2 & Ketepatan isi dalam kartu setiag kotalk dengan teori efikasi diri & 3 & 3 & $\overline{\mathrm{D}}$ \\
\hline 3 & Ketepatan pemilihan gambar dan pemberian makna & 3 & 4 & C \\
\hline 4 & Ketepatan pemilihan wama media & 2 & 4 & C \\
\hline \multicolumn{5}{|c|}{ Kegunaan } \\
\hline 1 & $\begin{array}{l}\text { Penggunaan pernyataan dalam media permainan Ular Tangga } \\
\text { Keyakinan }\end{array}$ & 4 & 4 & $\mathrm{D}$ \\
\hline 2 & $\begin{array}{l}\text { Penggunaan pertanyaan dalam media permainan Ular Tangga } \\
\text { Keyakinan }\end{array}$ & 2 & 4 & C \\
\hline 3 & $\begin{array}{l}\text { Penggunaan game truth or dare dalam media permainan Ular } \\
\text { Tangga Keyakinan }\end{array}$ & 3 & 4 & C \\
\hline 4 & $\begin{array}{l}\text { Penggunaan kata-kata motivasi dalam media permainan Ular } \\
\text { Tangga Kevakinan }\end{array}$ & 4 & 4 & $\mathrm{D}$ \\
\hline 5 & $\begin{array}{l}\text { Kegunaan media permainan Ular Tangga Keyalcinan untuk } \\
\text { memfasilitasi layanan BK }\end{array}$ & 4 & 4 & $\mathrm{D}$ \\
\hline \multicolumn{5}{|c|}{ Kelayakan } \\
\hline 1 & Kemudahan dalam memahami isi materi dalam kartv & 3 & 3 & $\mathrm{D}$ \\
\hline 2 & $\begin{array}{l}\text { Urairan isi materi yang ada dalam kartu media permainan } \\
\text { Ular Tangga Kevakinan }\end{array}$ & 3 & 4 & $\mathrm{C}$ \\
\hline \multicolumn{5}{|c|}{ Kemenarikan } \\
\hline 1 & Bentuk visualisasi media permainan Ular Tangga Keyakinan & 4 & 4 & $\mathrm{D}$ \\
\hline 2 & Memicu interaktifitas & 3 & 4 & C \\
\hline
\end{tabular}

Berdasarkan tabel 1, proses kuantifikasi hasil dari uji ahli materi menggunakan inter-rater agreement model, sebagai berikut.

Tabel 2. Hasil Kuantifikasi Uji Ahli Materi 
PENDAPAT AHLI 1

\begin{tabular}{clc|c|} 
PENDAPAT & \multicolumn{1}{l}{$\begin{array}{l}\text { Relevansi } \\
\text { Rendah (1-2) }\end{array}$} & \multicolumn{1}{c}{$\begin{array}{c}\text { Relevansi } \\
\text { tinggi (3-4) }\end{array}$} \\
\hline AHLI 2 & $\begin{array}{l}\text { Rendahsi (1-2) } \\
\text { Relevensi } \\
\text { tinggi (3-4) }\end{array}$ & 0 & 1 \\
\cline { 3 - 4 } & & 6 & 6 \\
\hline
\end{tabular}

Penentuan indeks uji ahli materi menggunakan rumus:

$$
\begin{aligned}
\text { Indeks Uji Ahli } & =\frac{D}{(A+B+C+D)} \\
\text { Indeks Uji Ahli } & =\frac{6}{(0+1+6+6)} \\
& =\frac{6}{13}=0,46 .
\end{aligned}
$$

Hasil uji ahli materi sebesar 0,46, di mana termasuk dalam kategori nilai 0,33-0,65. Menurut ahli materi 1 dan 2 mengenai kelayakan media permainan Ular Tangga Keyakinan cukup baik atau cukup layak digunakan untuk media Bimbingan dan Konseling. Ahli materi satu memberikan saran yaitu kartu pertanyaan sebaiknya dikasih pertanyaan yang bisa meransang siswa untuk menjawab hal positif, sedangkan ahli materi dua tidak memberi saran hanya memberi komentar yaitu sudah baik (lanjutkan). Saran tersebut dimanfaatkan sebagai penyempurnaan isi dari media permainan Ular Tangga Keyakinan yaitu penggunaan kartu pertanyaan agar siswa bisa menjawab pertanyaan yang bisa meningkatkan efikasi diri.

\begin{tabular}{|c|c|c|c|c|}
\hline \multirow{2}{*}{ No } & \multirow{2}{*}{ Aspek yang dinilai } & \multicolumn{2}{|c|}{ Penilaian } & \multirow{2}{*}{$\begin{array}{c}\text { Tabulasi } \\
\text { silang }\end{array}$} \\
\hline & & Ahli 1 & Ahli 2 & \\
\hline \multicolumn{5}{|c|}{ Ketepatan } \\
\hline 1 & $\begin{array}{l}\text { Ketepatan penggunaan bahasa dengan kemampuan siswa } \\
\text { SMP }\end{array}$ & 4 & 4 & $\mathrm{D}$ \\
\hline 2 & Ketepatan isi dalam kartu setiap kotak dengan teori efikasi diri & 4 & 4 & $\mathrm{D}$ \\
\hline 3 & Ketepatan pemilihan gambar dan pemberian makna & 2 & 3 & $\mathrm{C}$ \\
\hline 4 & Ketepatan pemilihan wama media & 3 & 3 & $\mathrm{D}$ \\
\hline \multicolumn{5}{|c|}{ Kegunaan } \\
\hline 1 & $\begin{array}{l}\text { Penggunaan pernyataan dalam media permainan Ular Tangga } \\
\text { Keyakinan }\end{array}$ & 4 & 4 & $\mathrm{D}$ \\
\hline 2 & $\begin{array}{l}\text { Penggunaan pertanyaan dalam media permainan Ular Tangga } \\
\text { Keyakinan }\end{array}$ & 4 & 4 & $\mathrm{D}$ \\
\hline 3 & $\begin{array}{l}\text { Penggunaan game truth or dare dalam media permainan Ular } \\
\text { Tangga Keyakinan }\end{array}$ & 2 & 3 & C \\
\hline 4 & $\begin{array}{l}\text { Penggunaan kata-kata motivasi dalam media permainan Ular } \\
\text { Tangga Kevakinan }\end{array}$ & 3 & 4 & C \\
\hline 5 & $\begin{array}{l}\text { Kegunaan media permainan Ular Tangga Keyakinan untuk } \\
\text { memfasilitasi layanan BK }\end{array}$ & 4 & 4 & $\mathrm{D}$ \\
\hline \multicolumn{5}{|c|}{ Kelayakan } \\
\hline 1 & Kemvdahan dalam memahami isi materi dalam kartv & 3 & 3 & $\mathrm{D}$ \\
\hline 2 & $\begin{array}{l}\text { Uraian isi materi yang ada dalam kartu media permainan Ular } \\
\text { Tangga Kevalkinan }\end{array}$ & 3 & 3 & $\mathrm{D}$ \\
\hline \multicolumn{5}{|c|}{ Kemenarikan } \\
\hline 1 & Bentuk visualisasi media permainan Ular Tangga Keyakinan & 3 & 3 & $\mathrm{D}$ \\
\hline 2 & Memicu interaktifitas & 3 & 4 & $\mathrm{C}$ \\
\hline
\end{tabular}

Tabel 3. Penilaian Uji Ahli Media

Berdasarkan tabel 3, kuantifikasi hasil dari uji ahli media sebagai berikut. 


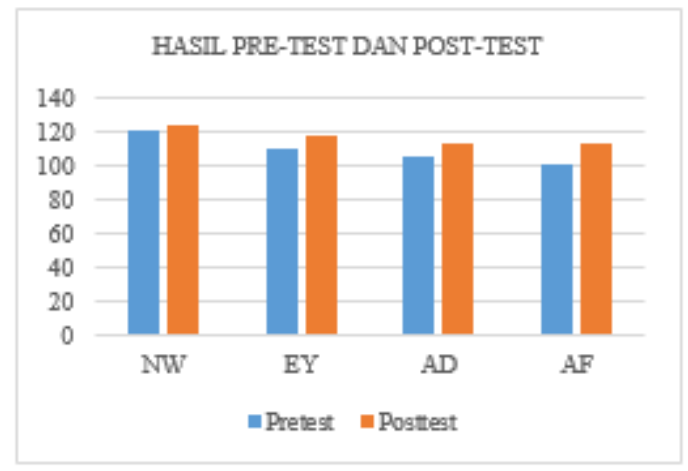

Gambar 5. Hasil Pretest-Posttest

\section{Pembahasan}

Permainan ular tangga kaitannya dengan efikasi diri adalah sebagai media permainan dalam Bimbingan dan Konseling yang dimodifikasi sesuai tujuan untuk meningkatkan efikasi diri siswa. Efikasi diri sangatlah penting bagi siswa karena dalam menjalani kehidupan seharihari perlu keyakinan diri yang tinggi, karena seseorang yang mempunyai keyakinan diri tinggi mereka akan dengan mudah melakukan sesuatu dengan bijak tanpa rasa ragu di dalam hatinya. Permainan ular tangga bisa digunakan untuk media pembelajaran yang memiliki banyak kelebihan salah satunya mengajarkan siswa untuk belajar sambil bermain sehingga bisa lebih menarik perhatian siswa dan menjadikan siswa belajar lebih efektif.

Permainan Ular Tangga Keyakinan mengajarkan siswa untuk mempunyai keyakinan bahwa bisa mencapai apa yang diharapkan. Dari 50 kotak yang ada dipermainan siswa harus bisa mencapainya, kadang kala siswa mendapatkan kotak yang bergambar kepala ular dimana artinya siswa harus turun. Kondisi ini menggambarkan bahwa siswa harus mempunyai keyakinan untuk maju, keyakinan untuk bisa mencapai apa yang diharapkan meski sering kali jatuh atau gagal. Ketika siswa mendapatkan kotak bergambar tangga, di situlah siswa merasa mendapatkan kemajuan dalam keyakinan dirinya. Saat permainan siswa akan dengan sendirinya mempunyai keyakinan tentang keinginan untuk bisa mencapai kotak yang diinginkan dan berharap tidak mendapatkan angka dadu yang merujuk pada kotak kepala ular dimana artinya siswa mengalami penurunan.

Menurut Pravesti, et al (2020), ketika individu mempunyai keyakinan akan dirinya yang memudahkan dalam proses pemahaman serta dalam menentukan strategi belajar yang efesien. Hal tersebut di atas, lebih lanjut diungkapkan bahwa kebutuhan untuk mencari bantuan yang diperlukan dalam mendukung proses belajar dapat tercapai dan sukses. Penelitian yang mendukung keefektifan ular tangga dalam peningkatan efikasi diri siswa yaitu penelitian yang dilakukan oleh Fransisca (2020) dalam meningkatkan efikasi diri melalui permainan ular tangga edukasi, dengan hasil penelitian $80,16 \%$ efektif dapat meningkatkan percaya diri anak. Penelitian lain yang dilakukan oleh Apriliana (2015) dengan hasil penelitian menunjukkan bahwa pengembangan ular tangga untuk meningkatkan percaya diri siswa diterima secara teoritis dan praktis.

Perbaikan dari ahli materi dan media menitik beratkan pada kegunaan kartu pertanyaan. Kaitannya dengan kartu pertanyaan dalam media permainan Ular Tangga Keyakinan, sebelumnya pengembang sudah membuat kartu pertanyaan sesuai dengan indikator efikasi diri dengan tujuan untuk meningkatkan efikasi diri. Ada beberapa kartu pertanyaan yang jawabannya mengarah pada jawaban negatif, untu itu perlu adanya perbaikan atau revisi untuk kesempuranaan media permainan Ular Tangga Keyakinan. Perbaikan pada penggunaan kartu pertanyaan pada jawaban siswa yang mengarah pada jawaban negatif, diperbaiki dengan 
menganti pertanyaan yang sifatnya positif atau mengarah pada jawaban positif, agar jawaban siswa saat mendapat kartu pertanyaan mengarah pada jawaban positif atau terbuka.

Hasil masukan dari ahli materi dan media mengenai kartu pertanyaan, perlu adanya perbaikan atau perubahan isi pertanyaan yang ada dalam kartu pertanyaan. Perbaikan tersebut tidak merubah konteks pembahasan dari seriap indikator, tetapi pengembang hanya memperbaiki pertanyaan menjadi lebih spesifik. Pengembang mengajak pemain untuk menjawab pertanyaan secara khusus sesuai dengan keadaan mereka. Penilaian dari para ahli mengatakan bahwa media permainan Ular Tangga Keyakinan efektif atau layak dipergunakan sebagai media BK di SMP, karena memenuhi unsur ketepatan, kegunaan, kelayakan, dan kemenarikan. Hal tesebut dibuktikan dengan penilaian dari para ahli yang dihitung menggunakan inter-rater agreement model.

Ketepatan permainan Ular Tangga Keyakinan sebagai media yang sudah diberikan para ahli BK dan media didasarkan pada konsep teori efikasi diri Bandura. Teori efikasi diri yaitu keyakinan terhadap kemampuan untuk melaksanakan tindakan guna mencapai yang diinginkan. Konsep Ular Tangga Keyakinan merujuk pada permainan ular tangga yang diibaratkan sebagai permainan perjalanan hidup menuju suatu tujuan perjalanan hidup kadang kala dihadapkan pada keberhasilan atau kegagalan.

Selain itu media permainan Ular Tangga Keyakinan masuk dalam kriteria pemilihan media BK yang dikemukakan oleh (Nursalim, 2013) yaitu 1) sesuai dengan tujuan dan materi BK terhadap teori efikasi diri, 2) penjelasan latar belakang yang terpapar dalam buku panduan untuk memudahan pengguna memahami tujuan dari pengembangan media, 3) kesan tampak menarik dengan unsur dua dimensi, dan 4) adanya efesiensi waktu bimbingan. Hasil uji pengguna diperoleh gambaran bahwa media permainan Ular Tangga Keyakinan tepat dan berguna dalam mendukung layanan Bimbingan dan Konseling, karena pengembangannya berdasarkan hasil kebutuhan siswa.

Berdasarkan hasil pedoman obervasi yang dilakukan oleh guru BK dari pertemuan pertama hingga pertemuan keempat dikatakan berjalan dengan baik meskipun di awal ada sedikit catatan, dengan perolehan skor prosentase sebesar 79\%, 86\%, 86\%, dan 89,2\%. Dari hasil uji pengguna diperoleh di lapangan adanya permasalahan seputar ukuran font (tulisan) pada media permainan Ular Tangga Keyakinan. Menurut pengguna atau Konselor perlu diperhatikan agar ukuran tulisan di perbesar sedikit lagi. Hal tersebut digunakan sebagai acuan dalam perbaikkan media permainan Ular Tangga Keyakinan sehingga ukuran font pada media permainan Ular Tangga Keyakinan direvisi dan diperbesar lagi, sehingga dapat memperjelas siswa ketika membacanya.

Skor yang didapat dari ahli maeri dan media sebesar $94 \%$ dan $88 \%$, serta guru BK (calon pengguna) sebesar $92 \%$, dengan rata-rata nilai keseluruhan sebesar $91 \%$ dengan artian masuk dalam kategori nilai sangat baik. Kesimpulannya yakni media permainan Ular Tangga Keyakinan telah memnuhi kriteria ketepatan, kegunaan, kelayakan, dan kemenarikan, sehingga dapat digunakan sebagai media layanan BK untuk siswa SMP.

\section{SIMPULAN}

Media permainan Ular Tangga Keyakinan efektif meningkatkan efikasi diri siswa SMP. Peningkatan tersebut berdasarkan hasil pre-test dan post-test melalui instrumen skala efikasi diri dan pemberian treatment menggunakan media permainan Ular Tangga Keyakinan. Media permainan UTK memuat indikator-indikator efikasi diri yang dikemas dengan kartu pertanyaan, kartu pernyataan, game truth or dare, dan kata motivasi yang bertujuan untuk membantu meningkatkan efikasi diri siswa SMP. Segi validitas media permainan Ular Tangga Keyakinan 
menyatakan bahwa hasil uji ahli materi, media, dan pengguna layak digunakan sebagai media BK di SMP, tentunya sudah melewati beberapa revisi.

Saran bagi guru BK yaitu penelitian pengembangan dapat bermanfaat bagi guru BK dalam melaksanakan layanan BK di sekolah menggunakan media permainan UTK khususnya untuk meningkatkan efikasi diri siswa. Saran bagi peneliti atau pengembang selanjutnya yaitu penelitian pengembangan ini mengharapkan peneliti selanjutnya dapat mengembangkan media permainan Ular Tangga Keyakinan dengan pendekatan atau fokus penelitian yang berbeda yang lebih inovatif lagi serta dapat bermanfaat bagi siswa dalam belajar. Terakhir, saran bagi Ilmu BK yaitu dapat memberikan kontribusi bagi ilmu Bimbingan dan Konseling terkait layanan BK di sekolah.

\section{DAFTAR PUSTAKA}

Afandi, R. (2015). Pengembangan Media Pembelajaran Permainan Ular Tangga Untuk Meningkatkan Motivasi Belajar Siswa Dan Hasil Belajar IPS Di Sekolah Dasar. JINop (Jurnal Inovasi Pembelajaran), 1(1), 77-89.

Alwisol. (2009). Pikologi Kepribadian (R. Setyono (ed.); Revisi). UMM Press.

Anggriana, T.M., Kadafi, A., \& Trisnani, R. (2016). Pengaruh Efikasi Diri dan Internal Locus Of Control Terhadap Perencanaan Karir Mahasiswa Prodi Bimbingan dan Konseling IKIP PGRI Madiun. Counsellia: Jurnal Bimbingan Dan Konseling, 6(1), 86-96.

Apriliana, S. (2015). Pengembangan Materi Bimbingan Peningkatan Kepercayaan Diri Melalui Permainan Ular Tangga Untuk Siswa Sekolah Menengah Pertama (SMP). Jurnal Bimbingan Dan Konseling, 2(4), 68-80.

Arsyad, A. (2007). Media Pembelajaran. PT RajaGrafindo Persada.

Bandura, A. (1997). Self-Efficacy by A. Bandura 1997. W.H. Freeman and Company.

Borg, W. R \& Gall, M. D. (1989). Educational Research An Introduction (5th Ed). Logman.

Duma, N. (2015). Manfaat Bermain Ular Tangga. Nancy Duma. www.nancyduma.com

Fransisca, R. (2020). Meningkatkan Percaya Diri Anak Dengan Permainan Ular Tangga Edukasi. Jurnal Obsesi: Jurnal Pendidikan Anak Usia Dini, 4(2), 630-638. https://doi.org/10.31004/obsesi.v4i2.405

Fratturar. (2018). How important is self-efficacy to our srudents' succes? Sites.Wit.Edu. https://sites.wit.edu/lit/how-important-is-self-efficacy-to-our-students-succes/

Ghufron, M. N. (2010). Teori-teori Psikologi (1st ed.). Ar-Ruzz Media.

Gregory, R. J. (2011). Psychologycal Testing. History, Principles, and Aplications (6th Ed). Boston: Allyn \& Bacon.

Makaria, E. C., Rachman, A., Rachmayanie, R., \& Mangkurat, U. L. (2019). Korelasi Kepercayaan Diri dan Efikasi Diri Akademik Mahasiswa Program Studi Bimbingan Dan Konseling Angkatan 2018. 5(1), 1-5.

Melsi, A. (2015). Efektivitas Penggunaan Media Permainan Ular Tangga Terhadap Hasil Belajar Kognitif Siswa pada Materi Virus di Kelas X SMA Nusantara Indah Sintang Tahun Pelajaran 2015/2016. STKIP Persada Khatulistiwa Sintang.

Nursalim, M. (2013). Pengembangan Media Bimbingan dan Konseling. Jakarta:Indeks. https://scholar.google.co.id

Pravesti, C.A., Wiyono, B.B., Handarini, D.M., Triyono \& Atmoko, A. (2020). Examining The Effects of Guidance and Counseling Services to The Self-Regulated Learning for College Students. Journal for the Education of Gifted Young Scientists, 8(1), 33-45. https://doi.org/http://dx.doi.org/10.17478/jegys.

Puri, L. W., \& Astuti, B. (2018). Profil Efikasi Diri Siswa MAN Wonokromo Bantul. Counsellia: Jurnal Bimbingan Dan Konseling, 8(2), 135-141. https://doi.org/10.25273/counsellia.v8i2.3243

Setyaputri, Y. N. (2015). Pengembangan Media Permainan Roda Pelangi untuk Meningkatkan 
Efikasi Diri Siswa dalam Menghadapi Ujian. Bimbingan dan Konseling, 28(1), 38-46. https://scholar.googe.co.id

Sukmadinata, N. S. (2016). Metode Penelitian Pendidikan (KE-11). PT Remaja Rosdakarya.

Tumu, Dj. N. (2014). Hubungan Antara Percaya Diri Dengan Efikasi Diri Pada Siswa Kelas X Di SMA Negeri 2 Gorontalo. Bimbingan dan Konseling, 46, 978.

Zulfia, M. (2018). Hubungan Dukungan Sosial Dan Efikasi Diri Pada Siswa Di SMP Negeri 02 Jabon Sidoarjo [Universitas Islam Negeri Maulana Malik Ibrahim Malang]. http://etheses.uin-malang.ac.id 